\title{
PHYTOCHEMICAL SCREENING AND TEST OF ANTIOXIDANT ACTIVITY IN THE EXTRACT OF MANGOSTEEN RIND
}

\author{
Rika Nailuvar Sinaga, Nurhamida Sari Siregar \\ Faculty of Sport Sciences, Universitas Negeri Medan (Unimed), Medan
}

\begin{abstract}
BACKGROUND: Mangosteen (Garcinia mangostana L.) rind had been known as an agriculture waste. However, some recent studies reported that Mangosteen rind had some health benefit. The rind (skin) of Mangosteen fruit was reported to contain compounds such as xanthones and anthocyanin antioxidants. There is a need to examine the chemical compound content of Mangosteen rind and the activities of antioxidants contained in the Mangosteen rind, so as to increase natural source of antioxidants for human health. This study aimed to produce ethanol extract of Mangosteen rind, to identify chemical compound content, and test its antioxidant activity.

SUBJECT AND METHODS: Ethanol extract of Mangosteen rind was produced to identify its chemical compound content. The DPPH method was used to test Mangosteen's antioxidant activity with $\mathrm{EC}_{50}$ as a measure of the fruit potency. Half maximal effective concentration (EC50) refers to the concentration of Mangosteen fruit which induces a response halfway between the baseline and maximum states after a specified exposure time. The $\mathrm{EC}_{5} \mathrm{O}$ of Mangosteen and vitamin $\mathrm{C}$ were compared.

RESULTS: Mangosteen rind extract consisted of saponin, tannins, polyphenol, triterpenoid, flavonoid, alkaloid and glycoside. The DPPH test of antioxidant activity showed that the $\mathrm{EC}_{50} \mathrm{O}$ of Mangosteen was 8.85 $\mu \mathrm{g} / \mathrm{ml}$, which exceeded the EC50 of $4.55 \mu \mathrm{g} / \mathrm{ml}$ in vitamin C.

CONCLUSION: Mangosteen rind extract consisted of saponin, tannin, polyphenol, triterpenoid, flavonoid, alkaloid and glycoside. Mangosteen rind extract has a strong antioxidant activity.
\end{abstract}

Keywords: mangosteen rind, phytochemical screening, antioxidant 